Article

\title{
Sustainability Analysis of the M-30 Madrid Tunnels and Madrid Río after 14 years of Service Life
}

\author{
Lucía López-de Abajo, Ana Patricia Pérez-Fortes $₫$, Marcos G. Alberti $₫$, Jaime C. Gálvez *(i) \\ and Tomás Ripa \\ Departamento de Ingeniería Civil, Construcción, E.T.S de Ingenieros de Caminos, Canales y Puertos, \\ Universidad Politécnica de Madrid, c/Profesor Aranguren, s/n, 28040 Madrid, Spain; \\ lucia.lopezdeabajo@upm.es (L.L.-d.A.); anapatricia.perez@upm.es (A.P.P.-F.); marcos.garcia@upm.es (M.G.A.); \\ tomasripa@1raingenieria.es (T.R.) \\ * Correspondence: jaime.galvez@upm.es; Tel.: +34-910674125
}

Received: 1 October 2020; Accepted: 17 October 2020; Published: 21 October 2020

\begin{abstract}
In 2007, the excavation of the M-30 ring road located in Madrid and the creation of a green corridor either side of the Manzanares river brought significant change to the metropolitan area. The corridor and linear park which it provided were designed to contribute to the regeneration of the fluvial ecosystem, establish links among residents on each side of the river and promote cultural and leisure activities. This paper provides a sustainability analysis of the excavation of the M-30 (involving the socio-economic and environmental impact) 14 years after its construction. In order to show such an impact, an analysis of the area both prior to the project and after completion, as well as a hypothetical solution that uses improved materials, has been performed. This entails use of the multi-criteria decision-making model named MIVES (initials in Spanish, modelo integrado de valor para una evaluación sostenible). The MIVES method is based on the application of value functions of sustainability indicators selected by socio-economic and environmental criteria, chosen by experts. Results from analysis showed that the excavation of the M-30 considerably improved the sustainability of the area (sustainable index 3.43 and 6.26 both before and after the excavation works). However, use of improved materials in contrast with the application of conventional materials slightly improved the sustainability of the work (Sustainability Index 6.26 and 6.74, respectively, of the conventional materials).
\end{abstract}

Keywords: sustainability; MIVES method; tunnels; construction materials; M-30

\section{Introduction}

The city of Madrid holds about 3.5 million of inhabitants and its metropolitan area is over 6 million [1]. These factors make Madrid the largest city in Spain and the fourth largest city in the European Union [2].

Madrid has worked on enhancing the sustainability of the city by improving transport infrastructure (such as urban ring roads and high occupancy vehicle lanes), green areas (such as Madrid Río linear park), the recycling system and supporting green business, among others [3]. As it is known that the improvement of transport infrastructures is vital for the socio-economic development, and also to improve mobility and safety [4-6], infrastructure investments play a major role on the sustainability of the cities. Additionally, sustainable transport entails a significant contribution on reaching urban sustainable development [7].

Madrid is surrounded by three ring roads (M-30, M-40, and M-50), Figure 1. The M-30 is the busiest one and that which passes closest to the city center, contributing $24.2 \%$ of the metropolitan area daily traffic and $9.4 \%$ of that of the greater Madrid region, with an average annual daily traffic about 
200,000 vehicles/day [8]. Its total length is about $32 \mathrm{~km}$, with a generic configuration of $3+3$ lanes except on the north part where it is an urban boulevard [1].

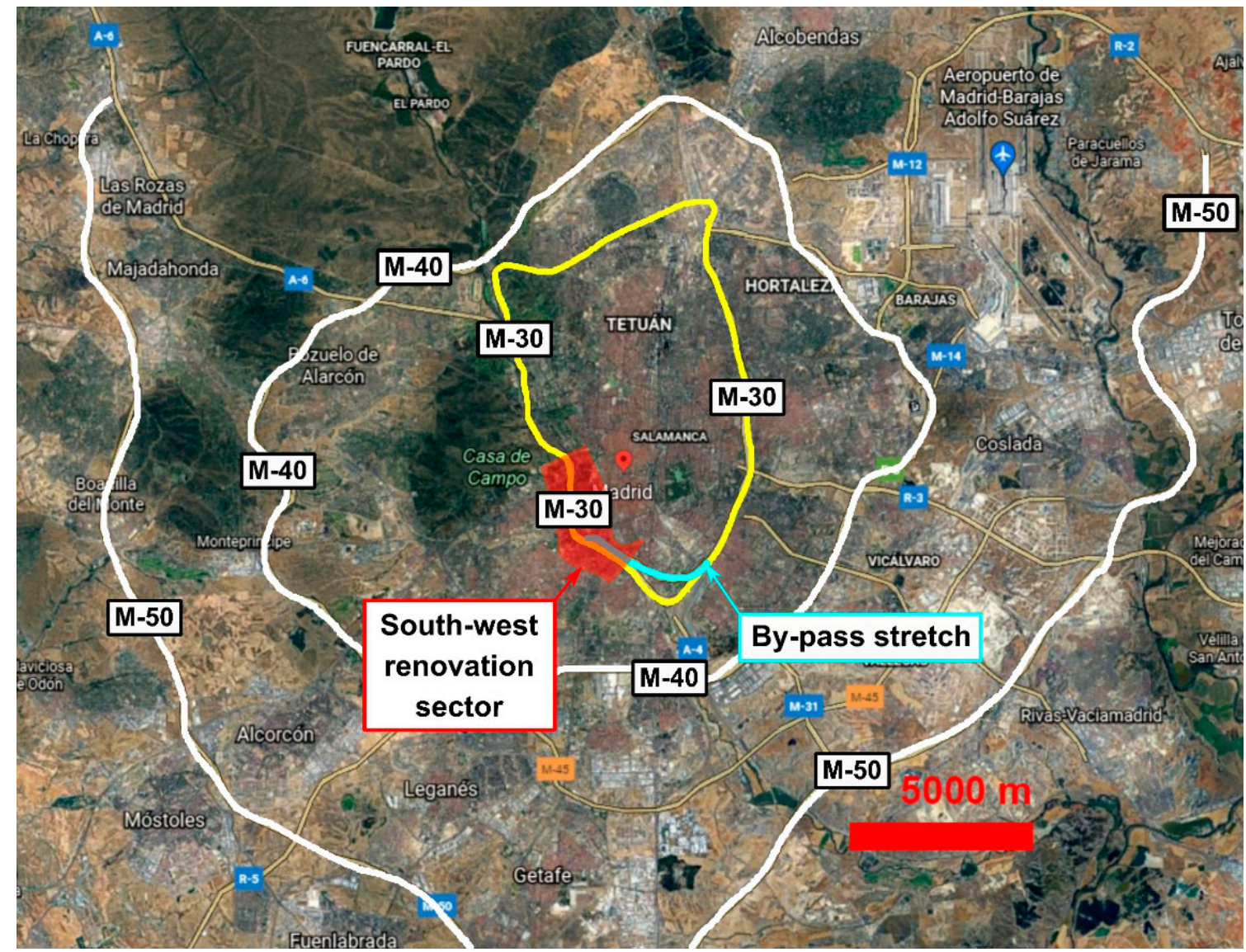

Figure 1. Location of the M-30 ring-road and surrounding districts. South-west area renovated in 2004-2007 to build the tunnels and Madrid Río park is highlighted in red.

It was built during the 1970s and 1990s with a heterogeneous design, combining sections with highway and urban characteristics regulated by traffic lights. Although this diversity of sections still exists, during its first years the M-30 encountered issues which concurrently compromised road safety in the area (an average 600 accidents and eight deaths per year from 1998 to 2002, [9]). One of the main reasons was an excessive amount of entrances and exits from the main stem and several (and too short) transfer sections between side and central lanes [9]. Furthermore, the M-30 is located in close proximity to the city center and crosses built-up areas, which has caused several environmental problems such as noise and air pollution [10]. These issues were especially severe on the west sector where the highway flowed over an extremely developed area, causing a significant barrier effect [9]. Therefore, a renovation of layout was needed to improve socio-economic and environmental conditions.

In such a way, renovation (carried out from 2004 to 2007) sought to increase the road service level and improve comfort and environmental conditions both of the road and the surrounding areas. Road service level was improved by homogenizing and relocating part of the road underground (with $8.8 \mathrm{~km}$ of tunnels being constructed [8]), reducing the accident rate and traffic congestion in the area. Such comfort and environmental conditions were improved by creating a new green corridor located in the south-west part of the city, Figure 1 [10]. This corridor aimed to decrease the environmental impact and fluency problems caused by the barrier effect of the road in nearby neighborhoods [8-10]. 
In this study, the sustainability analysis of the M-30 focuses on the works performed in its south-west stretch. This area was that most influenced by the new road design due to the burial of the layout and creation of a new green corridor, and public open space, named Madrid Río. The tunnels of this section were built through use of two typologies: an opencast tunnel with screen walls and a false ceiling (next to the Manzanares river) and a tunnel built by using two tunnel boring machines (TBMs) (a by-pass stretch, as shown in Figure 1) [11]. The tunnels offer high safety measures, such as accident and fire prevention, as well as several units and devices to control and ensure a suitable air quality. Indeed, they are fitted with a high amount of ventilation stations with ventilation areas about $600 \mathrm{~m}$ long to dilute the pollutant concentration inside of the tunnels [12]. Madrid Río is a linear park with 429 hectares of new green areas distributed along the banks of the Manzanares river with the aim of integrating the river environment into the urban landscape of Madrid [13]. Thus, the park offered not only an improvement of the environmental conditions but also eliminated the previous road barrier, linking the south with central Madrid, thus producing extensive urban regeneration of the area [14]. The materials used to build the tunnels should also be taken into account, as it is known that cement production contributes to global warming with $7-8 \%$ of global $\mathrm{CO}_{2}$ emissions [15]. The most effective ways to reduce emissions caused by such production entail incorporating by-products or waste materials as aggregates or reducing the amount of cement used and thus substituting part of the cement with by-products such as, among others, fly ash $[15,16]$. In this case, the tunnels were built by using conventional concrete. Such concrete types are those with a compression resistance of 20-30 MPa, reaching 35-45 MPa when used in pre-stressed concrete. Improved concretes are used when specific characteristics are required, such as self-compacting, high-strength, or lightweight types [17]. Considering use of improved concretes, such as the high-strength ones (compressive strength higher than $50 \mathrm{MPa}$ [18]), it should be noted that dosage would differ from that of conventional concretes. These kinds of concretes use a higher amount of cement $\left(400-500 \mathrm{~kg} / \mathrm{m}^{3}\right.$ ), lower water/cement ratio (less than 0.3 ), incorporate additives and additions such as superplasticizers and silica fume (in addition, the nature, type, and maximum size of the aggregates should also be carefully studied [17-19]. These concrete types can be of significant interest to improve the lifespan of the infrastructure, although they can affect to a greater extent the carbon footprint of the construction works. Moreover, the use of special concrete requires more technology and prior studies which could imply longer execution times. Hence, any assessment of the most sustainable solution should require thorough study.

The method applied to estimate the sustainability of the works performed on the south-west stretches of the M-30 is the multi-criteria decision-making model named MIVES (initials in Spanish, modelo integrado de valor para una evaluación sostenible) $[18,20,21]$. It has been well reported that the construction sector causes a significant environmental impact during material extraction and production, the building process, service life, and end of use and demolition of an infrastructure [22,23]. Therefore, to assess the sustainability of such an infrastructure, several factors and situations should be considered. In such a way, the aforementioned multi-criteria decision-making method (MCDM) is suitable when a large number of factors is considered and, especially, when such factors are on occasions difficult to measure. Additionally, these models are also able to integrate socio-economic factors into the environmental requirements [22]. In such a way, the MIVES method includes the environmental and socio-economic impacts of the infrastructure in the analysis. With this purpose, the inputs of the method have been a result of the factors and values defined and discussed during seminars delivered by experts [24]. Therefore, to assess the impact of M-30 works, MIVES was applied both before and after renovation, considering the current conditions and the 14 years of service life of the tunnels. During the last few years, new greener and improved materials have been used in the construction sector, such as recycled aggregates and self-compacting concrete. Therefore, an additional sustainability study of the section that considers materials is also performed.

Following this rationale, this research seeks to apply the MIVES method to the buried stretch of the south-west sector of the M-30 in Madrid. It is also the purpose of the paper to make a scientific 
analysis of several aspects that are mainly subjective and qualitative and turn them into objective and quantitative matters in order to analyze three different and possible alternatives:

(a) Non-buried M-30: in this situation, the former layout of the M-30 was considered, before the construction of the tunnels and the creation of the Madrid Río park.

(b) Buried M-30 by using conventional materials: this is the current condition of the road and, thus, the solutions to improve its environmental and socio-economic impact on the area were analyzed.

(c) Buried M-30 by using improved materials: this alternative considers the application of greener and improved construction procedures and materials to evaluate its influence on sustainability.

\section{The MIVES Method and Its Application to the Renovation of the South-West Section of M-30}

Considering the large number of heterogeneous factors that must be taken into account to perform this sustainability analysis, experience has shown the use of a multi-criteria decision-making method (MCDM) as the most suitable given that MCDM breaks down the problem studied into its elemental pieces so as to completely understand the evaluation process $[25,26]$. It is also noticeable that the selected method must be versatile enough to be applied to the great complexity of the infrastructure when analyzing socio-economic and environmental factors [5]. Additionally, it has been stated that sustainable engineering is an adequate field to use MCDM [27].

There are a wide range of methods to assess the sustainability of a building or a civil engineering work, but they have different scopes and approaches [22,25]. For instance, Life Cycle Assessment (LCA) $[16,22,28-34]$ evaluates the sustainability of a building analyzing its environmental burden during its life cycle, namely, it considers the environmental inputs, outputs and impact during the life service of an infrastructure. Another kind of analysis is the one carried out by Life Cycle Cost (LCC) $[16,22,35]$ which performs an economic study taking into account the purchasing and operating phases of the infrastructure in a period of time. Other complementary methods are: Life Cycle Energy Analysis (LCEA) [22,36] which studies the energy inputs over the service life of a infrastructure; Material Flow Analysis (MFA) [22,37] which analyses transformation, transport or storage of construction materials and Energy Flow Analysis (MEFA) $[22,38]$ which adds the energy flow to the study. However, previous researchers came to the conclusion that the methods mentioned above are not fully appropriate to evaluate the sustainability of infrastructures [26,27,39]. In addition, there are some MCDM used in the construction sector such as ANP, DEA/ELECTRE, TOPSIS, or PROMÉTHÉE which are only used in some geographical frameworks [30,31].

In this context, MIVES is a genuine MCDM as it combines a holistic discriminatory tree of requirements, criteria and indicators [5,22,40]; the value function concept [41] and seminars delivered by experts to evaluate the functions and weights using the Analytic Hierarchy Process (AHP) [22,26,42]. Therefore, this method allows researchers to obtain a scientific and sustainability-based rationale to make a decision between different alternatives [26]. Nevertheless, the main drawback of the method is that, as it involves an exhaustive and rigorous process and seminars delivered by experts on each field, it might not be suitable for urgent assessments [22].

Also, the MIVES method has already been used in several sustainability analysis of both architectural and civil works $[16,20,22-25,43-55]$, so taking into account the similarities between these projects and the case study of the M-30 burial, and considering the strengths of the method, MIVES was the chosen MCDM to perform this analysis. It is also remarkable that MIVES is the proposed method to evaluate the sustainability of concrete structures in the Spanish Structural Concrete Code EHE-08 [19,22,56,57].

As mentioned above, the MIVES method combines qualitative and quantitative factors for sustainability assessments in order to obtain a single general and non-dimensional sustainability index (SI, [58]). Therefore, before starting the process, an awareness of the problem and solutions should be obtained $[22,23,58]$. Once defined, a holistic decision tree with three levels (that is to say, requirements, criteria, and indicators) is required as shown in Figure 2. The indicators are evaluated by using value functions which turn the qualitative factors into quantitative variables with the same units 
and scales. Consequently, experts weight each requirement, criteria, and indicator in order to assess their importance in the model and the final SI. Lastly, the alternative solutions previously proposed are analyzed in order to select the most suitable one $[5,22,23,58]$.

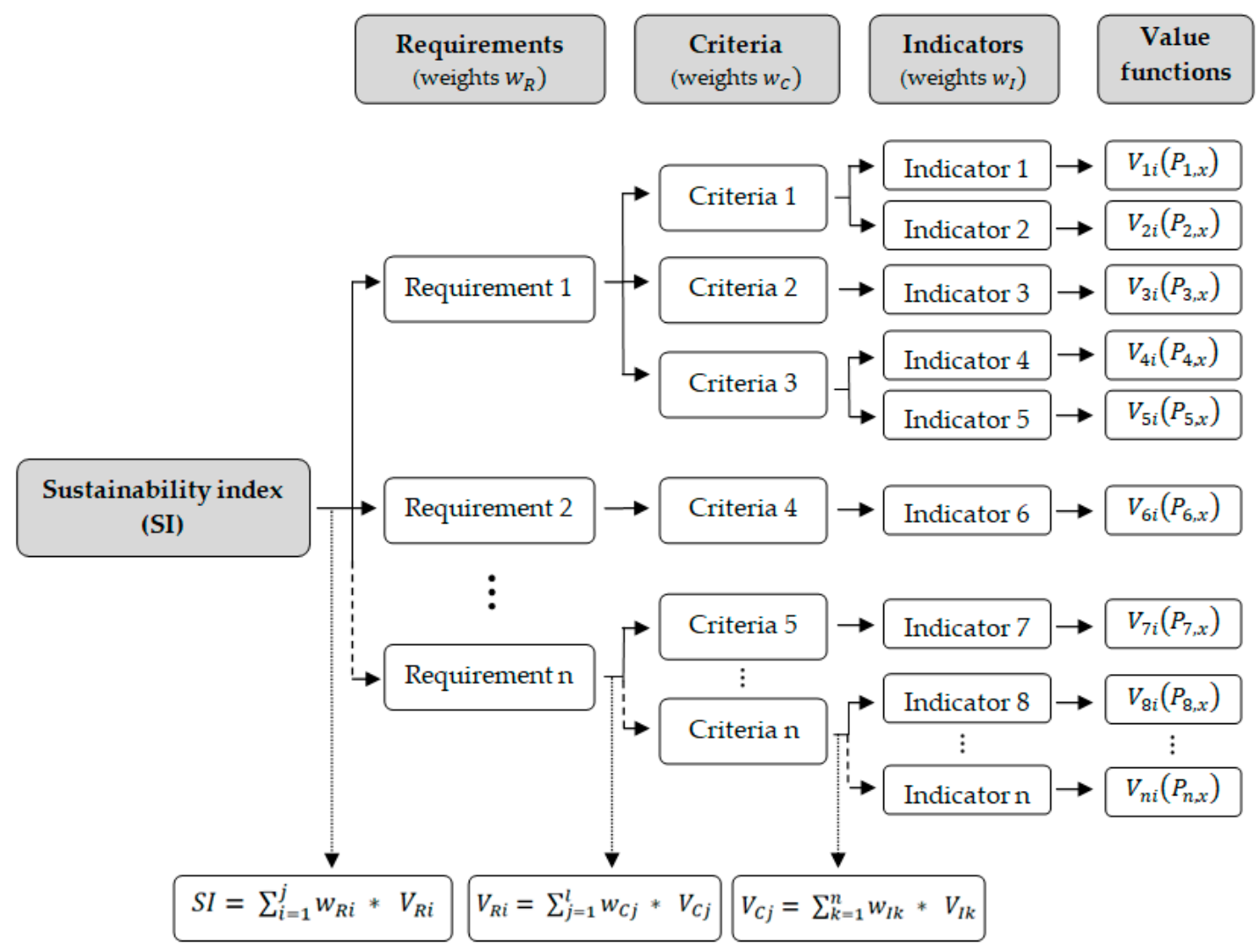

Figure 2. Structure of a generic modelo integrado de valor para una evaluación sostenible (MIVES) decision tree (modified from [40], Copyright CIMNE, 2016.).

Following the methodology, in order to assess the environmental and socio-economic benefits of renovation, especially on the south-west stretch, three alternatives were defined. They considered the influence of the construction materials used for the infrastructure, as follows:

(a) Non-buried M-30: in this situation, the former layout of the M-30 was considered, before the construction of the tunnels and the creation of the Madrid Río park.

(b) Buried M-30 by using conventional materials: this is the current condition of the road and, thus, the solutions to improve its environmental and socio-economic impact on the area were analyzed.

(c) Buried M-30 by using improved materials: this alternative considers the application of greener and improved construction procedures and materials to evaluate its influence on sustainability.

Once the alternative solutions to study the impact of the burial of the south-west corridor were defined, the requirements, criteria, and indicators to prepare the model were established as shown in Table 1 and described below.

It should be noted that the weights applied to each requirement, criterion, and indicator are a subjective matter, based on the opinion of experts and they are always defined prior to make any calculation in order to ensure its neutrality. The weights assigned in this research are based on literature review of previous studies of civil engineering works $[16,22,24]$ and adapted to this particular case, adding specific criteria and indicators and granting a special importance to the social aspects, as they are remarkably significant to this study. 
Table 1. Requirements, criteria, indicators, and weights.

\begin{tabular}{|c|c|c|c|c|c|}
\hline Requirements & (R. Weights) & Criteria & (C. Weights) & Indicators & (I. Weights) \\
\hline \multirow{8}{*}{ R1. Economic } & \multirow{8}{*}{$40 \%$} & C1 Total costs. Direct + Indirect & $30 \%$ & I1 Total costs, including construction time & $100 \%$ \\
\hline & & C2 Quality & $10 \%$ & I2 Non-quality costs & $100 \%$ \\
\hline & & C3 Dismantling & $10 \%$ & I3 Dismantling costs & $100 \%$ \\
\hline & & \multirow{2}{*}{ C4 Service-life } & \multirow{2}{*}{$30 \%$} & $\begin{array}{l}\text { I4 Cost of service. Maintenance. Energy. } \\
\text { Change of use. }\end{array}$ & $80 \%$ \\
\hline & & & & $\begin{array}{l}\text { I5 Resilience. Risk of disaster } \times \text { cost of } \\
\text { reconstruction }+ \text { lack of use }\end{array}$ & $20 \%$ \\
\hline & & \multirow{3}{*}{$\begin{array}{l}\text { C5 Benefits for the } \\
\text { surrounding area }\end{array}$} & \multirow{3}{*}{$20 \%$} & I6 Real-estate market & $50 \%$ \\
\hline & & & & I7 Tourism increase & $15 \%$ \\
\hline & & & & I8 Cultural boost & $35 \%$ \\
\hline \multirow{12}{*}{ R2. Environmental } & \multirow{12}{*}{$30 \%$} & \multirow{6}{*}{$\begin{array}{l}\text { C6 Material consumption at } \\
\text { construction time }\end{array}$} & \multirow{6}{*}{$15 \%$} & I9 Cement & $25 \%$ \\
\hline & & & & I10 Aggregates & $10 \%$ \\
\hline & & & & $\begin{array}{l}\text { I11 Reinforcement (steel mesh, steel fibres } \\
\text { and polyolefin fibres) }\end{array}$ & $15 \%$ \\
\hline & & & & I12 Water & $25 \%$ \\
\hline & & & & I13 Auxiliary materials & $15 \%$ \\
\hline & & & & I14 Reused material & $10 \%$ \\
\hline & & \multirow{6}{*}{$\begin{array}{l}\text { C7 Material consumption for } \\
\text { maintenance }\end{array}$} & \multirow{6}{*}{$20 \%$} & I9 Cement & $25 \%$ \\
\hline & & & & I10 Aggregates & $10 \%$ \\
\hline & & & & $\begin{array}{c}\text { I11 Reinforcement (steel mesh, steel fibres } \\
\text { and polyolefin fibres) }\end{array}$ & $15 \%$ \\
\hline & & & & I12 Water & $25 \%$ \\
\hline & & & & I13 Auxiliary materials & $15 \%$ \\
\hline & & & & I14 Reused materials & $10 \%$ \\
\hline
\end{tabular}


Table 1. Cont.

\begin{tabular}{|c|c|c|c|c|c|}
\hline Requirements & (R. Weights) & Criteria & (C. Weights) & Indicators & (I. Weights) \\
\hline \multirow{12}{*}{ R2. Environmental } & \multirow{12}{*}{$30 \%$} & \multirow{2}{*}{$\begin{array}{l}\text { C8 Emissions at } \\
\text { construction time }\end{array}$} & \multirow{2}{*}{$10 \%$} & I15 Global-warming potential & $80 \%$ \\
\hline & & & & I16 Total waste & $20 \%$ \\
\hline & & \multirow{2}{*}{ C9 Emissions for maintenance } & \multirow{2}{*}{$10 \%$} & I15 Global-warming potential & $80 \%$ \\
\hline & & & & I16 Total waste & $20 \%$ \\
\hline & & \multirow{3}{*}{$\begin{array}{l}\text { C10 Emissions during } \\
\text { exploitation }\end{array}$} & \multirow{3}{*}{$20 \%$} & $\begin{array}{l}\text { I17 Carbon dioxide uptake by } \\
\text { cementitious materials }\end{array}$ & $15 \%$ \\
\hline & & & & I19 Speed limit dependent emissions & $25 \%$ \\
\hline & & & & I20 Particle pollution. Exploitation & $30 \%$ \\
\hline & & \multirow{3}{*}{ C11 Energy } & \multirow{3}{*}{$10 \%$} & I21 Embodied energy & $20 \%$ \\
\hline & & & & I22 Construction energy & $40 \%$ \\
\hline & & & & I23 Service and maintenance energy & $40 \%$ \\
\hline & & \multirow{2}{*}{$\begin{array}{l}\text { C12 Ecosystems in } \\
\text { Manzanares River }\end{array}$} & \multirow{2}{*}{$15 \%$} & I24 Pollution & $50 \%$ \\
\hline & & & & I26 Ecosystem (endemic flora and fauna) & $15 \%$ \\
\hline \multirow{6}{*}{ R3. Social } & \multirow{6}{*}{$30 \%$} & \multirow{6}{*}{ C13 Design } & \multirow{6}{*}{$20 \%$} & $\begin{array}{l}\text { I27 Comfort. Thermal, air and, } \\
\text { among others, noise }\end{array}$ & $10 \%$ \\
\hline & & & & I28 Noise pollution. Construction & $15 \%$ \\
\hline & & & & I19 Particles pollution. Construction & $15 \%$ \\
\hline & & & & I20 Traffic disturbances. Construction & $15 \%$ \\
\hline & & & & I28 Noise pollution. Maintenance & $15 \%$ \\
\hline & & & & I29 Particles pollution. Maintenance & $15 \%$ \\
\hline
\end{tabular}


Table 1. Cont.

\begin{tabular}{|c|c|c|c|c|c|}
\hline Requirements & (R. Weights) & Criteria & (C. Weights) & Indicators & (I. Weights) \\
\hline \multirow{11}{*}{ R3. Social } & \multirow{11}{*}{$30 \%$} & & & I30 Traffic disturbances. Maintenance & $15 \%$ \\
\hline & & \multirow{3}{*}{ C14 Risks } & \multirow{3}{*}{$30 \%$} & I31 Health and safety during construction & $20 \%$ \\
\hline & & & & $\begin{array}{c}\text { I33 Occupant safety. Risk of disaster } \times \text { cost } \\
\text { of life disruption }\end{array}$ & $20 \%$ \\
\hline & & & & I34 Accident rate. Exploitation & $20 \%$ \\
\hline & & \multirow{4}{*}{$\begin{array}{l}\text { C15 Accessibility and } \\
\text { traffic connectivity }\end{array}$} & \multirow{4}{*}{$20 \%$} & I36 Traffic fluency & $25 \%$ \\
\hline & & & & $\begin{array}{l}\text { I37 Traffic connectivity and districts } \\
\text { fluency (people) }\end{array}$ & $25 \%$ \\
\hline & & & & I38 Universal accessibility (people) & $25 \%$ \\
\hline & & & & I39 Commercial sector & $25 \%$ \\
\hline & & \multirow{3}{*}{ C16 Comfort. Exploitation } & \multirow{3}{*}{$30 \%$} & $\begin{array}{l}\text { I27 Comfort. Thermal, air and, } \\
\text { among others, noise }\end{array}$ & $30 \%$ \\
\hline & & & & I28 Noise pollution. Exploitation & $35 \%$ \\
\hline & & & & I40 Green and promenade areas & $35 \%$ \\
\hline
\end{tabular}


(1) Economic requirements: it has been widely reported that roads promote the economic development of a given territory, changing the mobility patterns of the population, improving accessibility and having direct repercussions on the standard of living of people who reside in urban areas $[40,59]$. Therefore, it is relevant to evaluate the balance between the direct costs of the construction and indirect economic benefits generated by renovation of surrounding areas. Thus, the direct costs considered are those resulting from both the construction of the infrastructure and the future operations of maintenance and dismantling (Table 1). In addition, the non-quality costs should be taken into account, given that they are defined as those costs generated when a product of inadequate quality is obtained [60] and, consequently, increases maintenance costs [61]. So, in this case, non-quality costs were included to estimate the economic repercussions of the possible rejections and consequence of not having, for instance, a proper quality control or highly qualified and experienced labor force. As studies have shown, conventional materials are cheaper than the improved ones, though they will need a more exhaustive maintenance in the future. Equally, the purpose of the designers was to improve the environmental and social-economic regeneration of the surrounding areas of the M-30, especially with the creation of Madrid Río [13]. Thus, the indirect economic benefits obtained from construction were, for example, the enhancement of the real-estate market and improvement of tourism in the area (Table 1).

(2) Environmental requirements: the criteria and indicators studied were related to the material and energy consumption during construction, exploitation, and maintenance of the infrastructure. These criteria and indicators were focused on differentiating the use of conventional and improved construction materials. It should be noted that dosage would differ from that of conventional concretes. These kinds of concretes use a higher amount of cement $\left(400-500 \mathrm{~kg} / \mathrm{m}^{3}\right)$, have a lower water/cement ratio (less than 0.3 ), incorporate additives and additions such as superplasticizers and silica fume $[17,19]$. The nature, type and maximum size of the aggregates are also carefully studied. Equally, it has been reported that transport is a significant and increasing source of air and noise pollution worldwide [13,62]. In particular, road transport is responsible for $93 \%$ of the environmental costs produced by traffic in Europe, which represent approximately $4 \%$ of the gross domestic product (GDP) of the area $[63,64]$. Therefore, the pollutant and noise emissions during the construction, exploitation, and maintenance of the road and tunnels analyzed were also considered (Table 1). Lastly, given that one of the main goals of the renovation of the M-30 entailed linking the fluvial system of the Manzanares river with the urban landscape of Madrid [13,65], the recovery of the Manzanares river ecosystems in the Madrid stretch of the river and related criteria was also considered.

(3) Social requirements: such requirements evaluate the positive and negative effects that the renovation of the M-30 implies on workers, users, and residents of the surrounding areas on the basis of the impact on people, their community and the way of life which may occur during project design, construction, and use of the road (Table 1, [66]). Equally, the criteria were also selected by considering that roads may produce direct or physical and indirect or physiological effects on workers, users and residents [67]. Therefore, social criteria with these direct or physical effects were those related with health and safety, such as air and noise pollution or accident rates (Table 1). By contrast, social criteria with indirect or psychological effects were, for example, those related with traffic and people fluency, travel time, and accessibility (Table 1).

Once the requirements, criteria, and indicators are established (Table 1), the value functions for each indicator should be defined. Value functions convert the criteria magnitudes and units into a common, non-dimensional value [22] and delimit the units of the function. In this case, indicators would take values between 0 and 10 , with 10 being the highest degree of social satisfaction and sustainability and 0 the lowest.

Lastly, the SI of each alternative of the M-30 considered: that is to say, non-buried, buried by using conventional materials and buried by applying new materials as calculated with Equations (1)-(3) [22]. 
The value of a generic criterion $\left(V_{C_{j}}\right)$ is supplied by Equation (1). It 1 shows the addition from $K=1$ to $n$ (where $n$ is the number of indicators that there are in the criterion) of the product of the value of each indicator group $\left(V_{I k}\right)$, by the weight associated with the same $\left(w_{\mathrm{IK}}\right)$.

The same approach is used in the assessment of the requirements, obtaining the value of a requested generic $\left(V_{R i}\right)$ in Equation (2), which expresses the sum from $j=1$ to $l$ (with $l$ being the number of criteria that are in the requirement) of the products of the value of each criterion of the Group $\left(J_{c v}\right)$, by the weight associated with the same $\left(w_{C j}\right)$.

Lastly, the rate of sustainability of a building (SI) is obtained by the sum of the dimensionless values of each of the requirements $\left(V_{R i}\right)$ multiplied by the weight corresponding to each of them $\left(w_{R i}\right)$ as shown in Equation (3). The subscript $i$ represents the number of established requirements, which is 3 (economic, social, and environmental) for sustainability studies.

$$
\begin{gathered}
V_{C j}=\sum_{k=1}^{n} w_{I k} \cdot V_{I k} \\
V_{R i}=\sum_{j=1}^{l} w_{C j} \cdot V_{c j} \\
S I=\sum_{i=1}^{j} w_{R i} \cdot V_{R i}
\end{gathered}
$$

\section{Results and Discussion}

The values of each indicator, criterion and requirement considered for the sustainability analysis of the renovation of the south-west sector of the M-30, as well as the SI for the three alternative solutions studied, are shown in Table 2. It can be observed that the SI of the buried M-30 situation doubles the SI of the previous layout of the road. However, the SI of the buried M-30 built with new materials is only 0.5 higher than by using conventional materials. These scores may be attributed to the premise that the M-30 regeneration was designed with consideration of the environmental and socio-economic and 1 enhancement of the area $[14,61,67]$ (Tables 1 and 2). In this sense, it may be observed that several of the indicators selected have the same value regarding the use or not of greener and high-performance materials, as they evaluated the difference between the buried and non-buried solutions (Table 2).

- Economic requirements: from the economic point of view, it is noticeable that indicators based on the costs of the infrastructure, especially its renovation and dismantling, have a value contrary to the renovation of the $\mathrm{M}-30(\mathrm{C} 1, \mathrm{C} 3$, Tables 1 and 2). It could be assumed that the first solution, the non-burial of the M-30 stretch, means that the tunnels and park are not built and does not imply any construction cost. Equally, it could also be assumed that the dismantling of a surface road layout will be cheaper than the dismantling of the tunnels. By contrast, although the renovation of the layout implied several direct and indirect costs, it could be observed that the costs generated during the service life of the structure and the indirect economic benefits of the surrounding area were considerably enhanced (C4, $C 5$, Tables 1 and 2). It should also be considered that the older an infrastructure is the more maintenance operations it will require. As the lifecycle of the structure progresses, its resistant capacity starts to decrease, as a consequence of the inevitable deterioration of the construction materials, such as the carbonation process and, among others, reinforcement corrosion. This deterioration is slower in the early years of the structure and faster when it is reaching the end of its lifecycle [68]. So when analyzing the service life of this particular infrastructure, it is clear that the first alternative (non-buried M-30) will be the most penalized, given that structures would be older and require more maintenance (to some extent, similar to those of bridges located on the same road such as the Avenida del Mediterráneo and Avenida de la Paz). Thus, given that the accident rate was remarkably higher [9], 
it would have demanded relevant measures to reduce such a rate and repair damage caused by vehicle collisions. Furthermore, some of the road restraint systems would have required modernization to meet the requirements included in the Spanish standards [69]. It should also be noted that as noise levels in the surroundings of the highway were higher than those accepted for urban and residential areas [10,70], installation of sound-absorbing acoustic screens would have been necessary. Concerning the construction of the tunnels with conventional or improved materials, the first option will require more maintenance than the second one (for this reason, material consumption will be higher, as well as noise production and pollution and traffic disturbances), as improved materials will have high-performance properties regarding durability and will need less maintenance. Additionally, the average price of dwellings around the M-30, considering the size and real-estate characteristics of the districts, the real-estate value between 2005 and 2015 increased by approximately 500 euros per square meter due to the improvements provided by works [71]. This increase in real-estate values is directly related to the creation of Madrid Río which has boosted cultural and leisure activities, as well as commercial activities, in the vicinity $[14,61,67]$. Due to the new green area created and its connection with relevant tourist attractions of Madrid, such as the Royal Palace, the Cathedral, the Matadero cultural and exhibition center and the Campo del Moro Gardens, Madrid Río has become a new tourist point of interest of the city. However, the whole potential of the infrastructure in this sense is not completely exploited, due to a lack of information offered to tourists [72]. It is also remarkable that the economic benefits for the city as a consequence of the tunnels are only dependent on the overall design of the infrastructure, as they are unaffected by the use of greener and improved materials.

- Environmental requirements: from the environmental point of view, function values of the material consumption at construction time (C6, Table 1) follow a similar trend to $\mathrm{C} 1$ and $\mathrm{C} 3$ (total costs and dismantling, Tables 1 and 2). Again, it could be assumed that non-modification of the road implies that no materials are used and then the impact of this factor is zero. By contrast, the burial of the M-30 involved consumption of several building materials, especially concrete which is made up by water, cement, aggregates, chemical additions and, in the case of reinforced structures, steel [73]. The environmental impact of the extraction, production and transport of these raw materials has been evaluated as a medium impact (I9-I13, Table 2). However, this impact increases when considering greener and improved materials; for example, high-strength concrete requires low water cement/ratios and high-strength aggregates [74,75]. That means that the consumption of cement will rise and, consequently, so will its environmental impact. Equally, the use of high-strength aggregates can raise the costs and environmental impact of the exploitation and transport of these materials, with it being the least sustainable alternative from the point of view of the environmental aspects during construction. It should also be mentioned that the trend of the function value concerning the use of recycled materials is different from that explained before (I14, Table 2). Non-recycled materials were used during the construction of the old and new layout. However, the third alternative considers the use of recycled materials as greener building materials, enhancing the sustainability of this indicator (Table 2). Moreover, the use of greener and improved materials such as high-performance or self-compacting concretes, improves the durability characteristics of the infrastructure, decreasing the number and scope of maintenance operations and extending its service life [76,77]. Thus, such an alternative is the most suitable (C6, Table 2).

Additionally, one of the aims of the renovation of the M-30 was to increase the capacity of the road and improve traffic flow [9]. Such improvement and the burial of the former layout were also responsible for the enhancement of environmental indicators in the area (C9, C10, Table 2). It may be observed that the emissions of noise and pollutants increased during the construction works of the M-30 (C8, Table 2). However, once the works were finished, the environmental benefits produced by the renovation of the road were easily recognized (Table 2). For example, as shown in Figure 3, before the construction of the tunnels (2006), in the district of Arganzuela 
(Figure 1) which is located in the south-west sector of the M-30, the noise level was above $75 \mathrm{dBA}$. By contrast, in 2011, it was generally about $60 \mathrm{dBA}$ except at the entrances and exits from the tunnels, where it was higher [10]. Spanish law [70] limits the noise levels to $65 \mathrm{dBA}$ in residential areas. Therefore, the score obtained with the function value will be 0 if this limit is exceeded. Considering $45 \mathrm{dBA}$ as an acceptable noise level (satisfaction value 10), the function value will exhibit a decreasing concave curve, where satisfaction will drop rapidly when approaching the point of minimum satisfaction (Figure 3, [22]). It is remarkable that the burial of the M-30 and the construction of the tunnels led to a reduction of noise pollution of the area [10]. However, although noise levels were lower after the works than before them, the value of the recovery has been considered medium (I28, Table 2) given that the increase of the traffic, especially in the access to the tunnels, has raised the noise disturbance in the area [10].

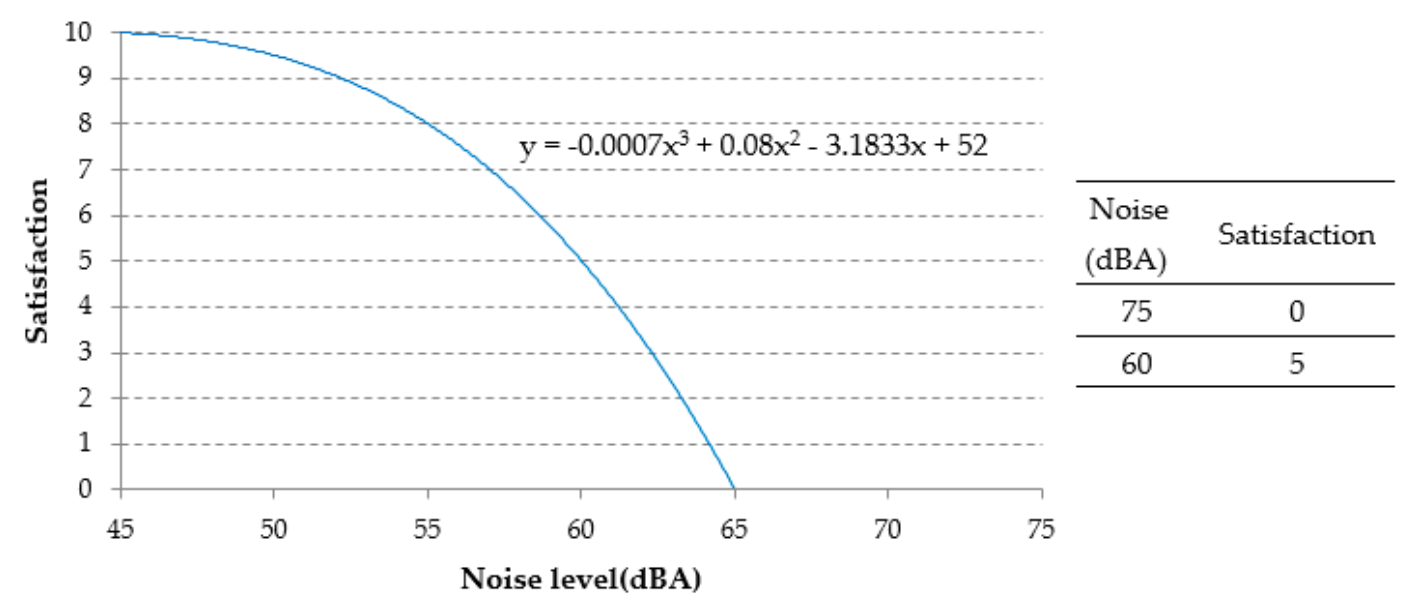

Figure 3. Value function for noise pollution during exploitation and scores obtained.

The same situation occurs with pollutant emission indicators (Table 2). Although emissions are lower than before the construction of the tunnels [10], they remain higher than the annual medium limit established by Spanish law for NOx gases $\left(40 \mu \mathrm{g} / \mathrm{m}^{3}\right.$, [78]). It should be mentioned that these emissions have also been reduced by the speed limit applied to the road, due to safety reasons, from $90 \mathrm{~km} / \mathrm{h}$ to $70 \mathrm{~km} / \mathrm{h}$ [1]. It has been shown that application of speed limits is an effective way to reduce vehicle emissions [79-81]. In particular, reducing it from $90 \mathrm{~km} / \mathrm{h}$ to $70 \mathrm{~km} / \mathrm{h}$ leads to a $15 \%$ and $16 \%$ reduction in $\mathrm{CO}_{2}$ and $\mathrm{NO}_{\mathrm{x}}$ emissions, respectively, on the M-30 (although emissions during peak hours may be increased) $[1,79,80]$. Therefore, given that speed limits in Spain range from $50 \mathrm{~km} / \mathrm{h}$ to $120 \mathrm{~km} / \mathrm{h}$, the indicator can be assessed for the speed limit dependent emissions function (I19, Table 2) the value 0 when speed limit is $120 \mathrm{~km} / \mathrm{h}$ (as it will provide higher emissions) and the value 10 when speed limit is $50 \mathrm{~km} / \mathrm{h}$. With a decreasing lineal function, as shown in Figure 4, the scores for the indicator at $90 \mathrm{~km} / \mathrm{h}$ (before the construction of the tunnels) and $70 \mathrm{~km} / \mathrm{h}$ (after the construction of the tunnels) are obtained. However, it must be noticed that these values of the function are only evaluating pollutant emissions depending on speed limits, as it is known that an excessive reduction of the speed limits will have negative impact on travel times and traffic fluency [1].

It should be highlighted that noise and pollutant emissions are, again, indicators independent from the materials selected in the structure. However, recent studies have shown that cement-based materials can absorb $\mathrm{CO}_{2}$ during their lifecycle $[15,81,82]$. In particular, during its lifecycle concrete can absorb $20 \%$ of the $\mathrm{CO}_{2}$ produced by calcination to manufacture the cement [15]. Therefore, the buried M-30 solution will have a greater $\mathrm{CO}_{2}$ uptake compared with the non-buried solution, as the volume of concrete used to build the structure is bigger. Equally, when comparing the use of conventional and high-performance materials, given that the latter will normally have a higher cement content [17] it could be considered that the $\mathrm{CO}_{2}$ uptake in this case will also be higher. 
Table 2. MIVES results for the analysis.

\begin{tabular}{|c|c|c|c|c|c|c|c|c|c|c|c|c|c|c|}
\hline \multirow[b]{2}{*}{ Requirements } & \multirow[b]{2}{*}{ Criteria } & \multirow[b]{2}{*}{ Indicators } & \multicolumn{4}{|c|}{ Non-Buried M-30 } & \multicolumn{4}{|c|}{ Buried M-30. Conventional Materials } & \multicolumn{4}{|c|}{ Buried M-30. Improved Materials } \\
\hline & & & $\begin{array}{c}\text { Score } \times \\
\text { Rweights }\end{array}$ & $\begin{array}{c}\text { Score } \times \\
\text { Cweights }\end{array}$ & $\begin{array}{c}\text { Score } \times \\
\text { Iweights }\end{array}$ & $\begin{array}{l}\text { Score } \\
(0-10)\end{array}$ & $\begin{array}{c}\text { Score } \times \\
\text { Rweights }\end{array}$ & $\begin{array}{c}\text { Score } \times \\
\text { Cweights }\end{array}$ & $\begin{array}{c}\text { Score } \times \\
\text { Iweights }\end{array}$ & $\begin{array}{l}\text { Score } \\
(0-10)\end{array}$ & $\begin{array}{c}\text { Score } \times \\
\text { Rweights }\end{array}$ & $\begin{array}{c}\text { Score } \times \\
\text { Cweights }\end{array}$ & $\begin{array}{c}\text { Score } \times \\
\text { Iweights }\end{array}$ & $\begin{array}{l}\text { Score } \\
(0-10)\end{array}$ \\
\hline \multirow{8}{*}{ R1. Economic } & $\mathrm{C} 1$ & I1 & \multirow{8}{*}{1.50} & 3.00 & 10.00 & 10 & \multirow{8}{*}{2.29} & 1.50 & 5.00 & 5 & \multirow{8}{*}{2.32} & 0.90 & 3.00 & 3 \\
\hline & $\mathrm{C} 2$ & $\mathrm{I} 2$ & & 0.10 & 1.00 & 1 & & 0.60 & 6.00 & 6 & & 0.80 & 8.00 & 8 \\
\hline & $\mathrm{C} 3$ & I3 & & 0.30 & 3.00 & 3 & & 0.10 & 1.00 & 1 & & 0.10 & 1.00 & 1 \\
\hline & \multirow{2}{*}{$\mathrm{C} 4$} & I4 & & \multirow{2}{*}{0.36} & 0.00 & 0 & & \multirow{2}{*}{1.98} & 5.60 & 7 & & \multirow{2}{*}{2.46} & 7.20 & 9 \\
\hline & & I5 & & & 1.20 & 6 & & & 1.00 & 5 & & & 1.00 & 5 \\
\hline & \multirow{3}{*}{ C5 } & I6 & & \multirow{3}{*}{0.00} & 0.00 & 0 & & \multirow{3}{*}{1.55} & 4.00 & 8 & & \multirow{3}{*}{1.55} & 4.00 & 8 \\
\hline & & I7 & & & 0.00 & 0 & & & 0.60 & 4 & & & 0.60 & 4 \\
\hline & & I8 & & & 0.00 & 0 & & & 3.15 & 9 & & & 3.15 & 9 \\
\hline \multirow{12}{*}{ R2. Environmental } & \multirow{6}{*}{$\mathrm{C} 6$} & I9 & \multirow{12}{*}{1.17} & \multirow{6}{*}{1.35} & 2.50 & 10 & \multirow{12}{*}{1.62} & \multirow{6}{*}{0.68} & 1.25 & 5 & \multirow{12}{*}{1.99} & \multirow{6}{*}{0.73} & 0.75 & 3 \\
\hline & & I10 & & & 1.00 & 10 & & & 0.50 & 5 & & & 0.40 & 4 \\
\hline & & I11 & & & 1.50 & 10 & & & 0.75 & 5 & & & 1.05 & 7 \\
\hline & & I12 & & & 2.50 & 10 & & & 1.25 & 5 & & & 1.25 & 5 \\
\hline & & I13 & & & 1.50 & 10 & & & 0.75 & 5 & & & 0.90 & 6 \\
\hline & & I14 & & & 0.00 & 0 & & & 0.00 & 0 & & & 0.50 & 5 \\
\hline & \multirow{6}{*}{ C7 } & I9 & & \multirow{6}{*}{0.20} & 0.25 & 1 & & \multirow{6}{*}{1.26} & 1.75 & 7 & & \multirow{6}{*}{1.72} & 2.25 & 9 \\
\hline & & I10 & & & 0.20 & 2 & & & 0.70 & 7 & & & 0.90 & 9 \\
\hline & & I11 & & & 0.15 & 1 & & & 1.05 & 7 & & & 1.35 & 9 \\
\hline & & I12 & & & 0.25 & 1 & & & 1.75 & 7 & & & 2.25 & 9 \\
\hline & & I13 & & & 0.15 & 1 & & & 1.05 & 7 & & & 1.35 & 9 \\
\hline & & I14 & & & 0.00 & 0 & & & 0.00 & 0 & & & 0.50 & 5 \\
\hline
\end{tabular}


Table 2. Cont.

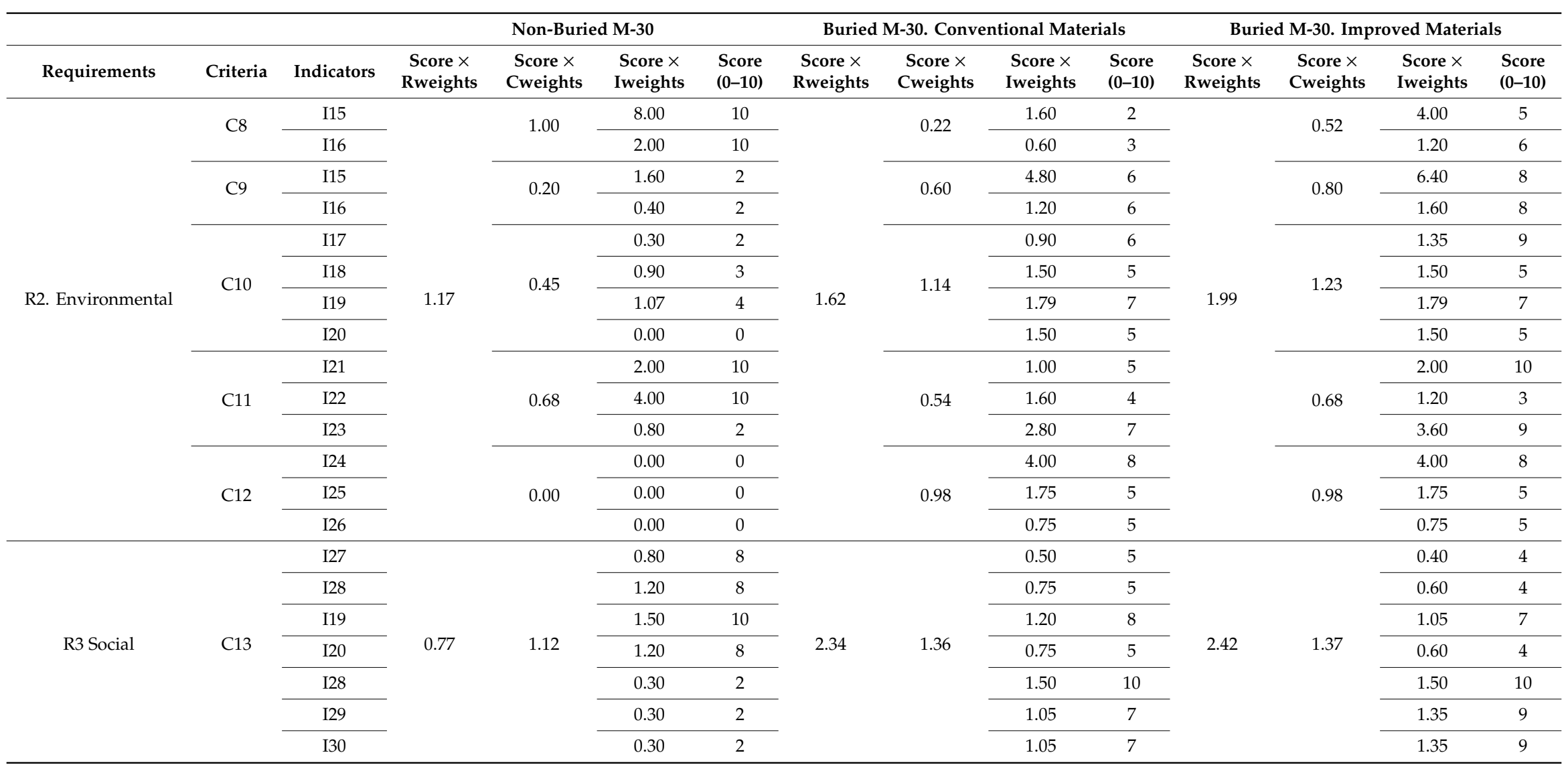


Table 2. Cont.

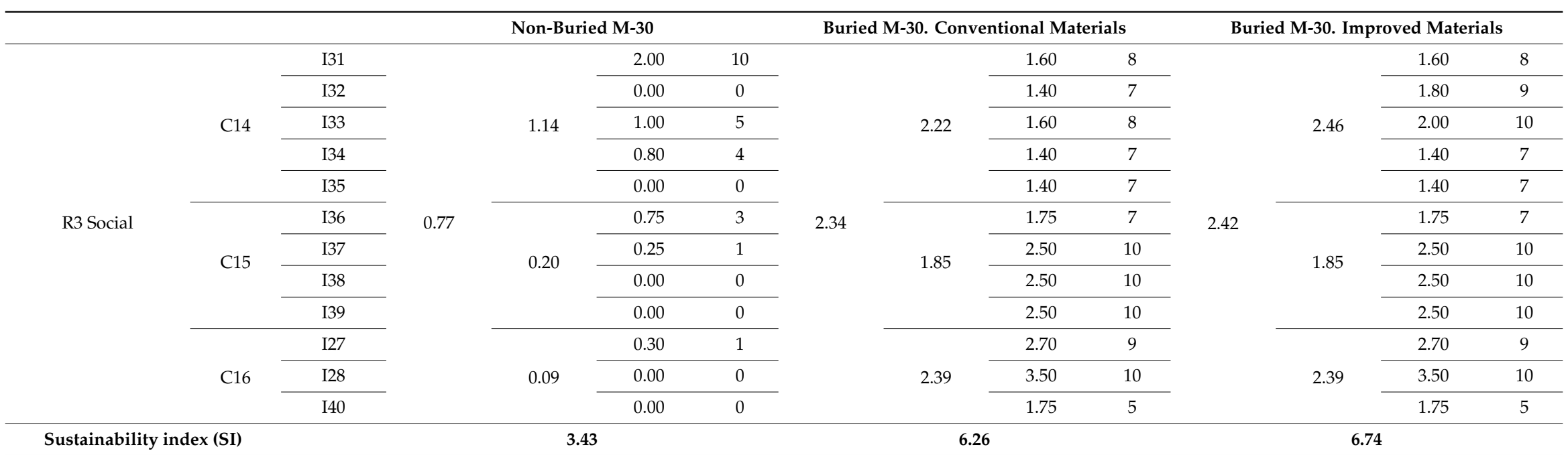

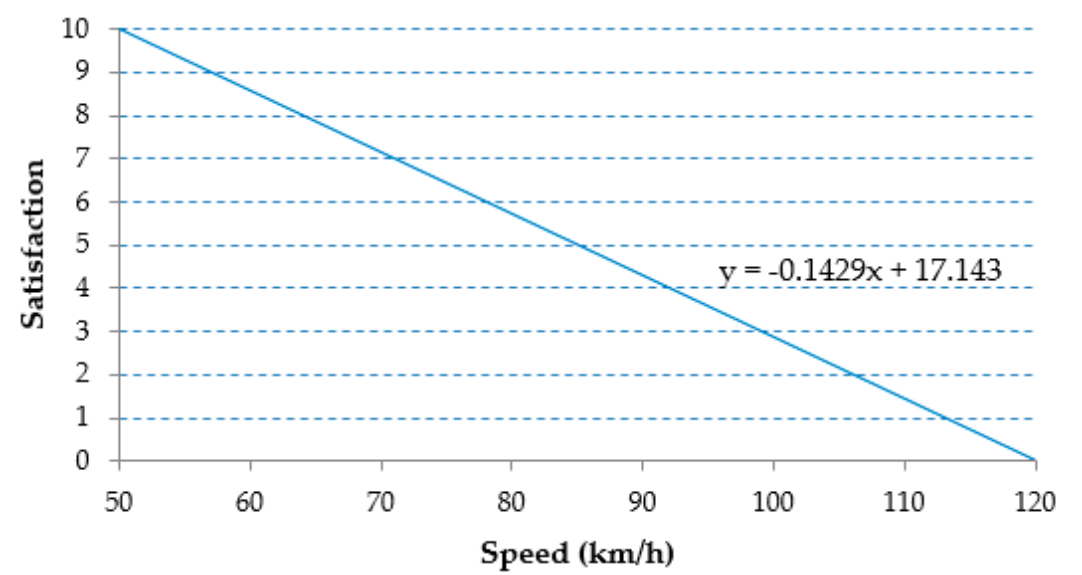

\begin{tabular}{cc}
\hline $\begin{array}{c}\text { Speed } \\
(\mathrm{km} / \mathrm{h})\end{array}$ & Satisfaction \\
\hline 90 & 4 \\
\hline 70 & 7 \\
\hline
\end{tabular}

Figure 4. Value function for speed-dependent emissions and scores obtained. 
Similar to the aforementioned indicators, energy consumption grew during the regeneration works, with this parameter being less suitable during this period of time. However, the new facilities built were designed to reduce energy consumption (for example, in the tunnels, where energy consumption savings are $21 \%$ or $3.73 \mathrm{MWh} /$ year) compared with the previous and due to the implementation of light-emitting diode (LED) technology and adjustment of the intensity of tunnel lighting according to the daylight [83], thus enhancing this indicator during the service life of the structure.

Lastly, the main action performed to improve the environmental sustainability of the south-west section was the creation of Madrid Río and recovery of the fluvial system and its ecosystem (C12, Table 2). The burial of the road and reuse of the land around the area as a green area with more than 33,000 newly planted trees and 470,000 shrubs, and 210,000 square meters of low water demand meadow, enables a reduction of 35,000 tons of $\mathrm{CO}_{2}$ from the air pollution, as well as the significant reduction of noise pollution $[14,61]$. However, the enhancement of these indicators has been considered medium because the original design of Madrid Río did not contribute to restoring the natural characteristics of the Manzanares river and additional actions were performed in subsequent years [84]. It is also notable that the criterion involving the fluvial ecosystems is only dependent on the design of the structure and use of new materials does not change its value (C12, Table 2).

- Social requirements: from the social point of view, the main disturbances (noise, dust and, among others, traffic congestion) produced by the M-30 renovation on the users and residents of the area should be taken into account (C13, Table 2). The works caused traffic interruptions and produced additional noise and pollutants (dust) in the area. However, the comfort of users and residents was widely increased with the construction of the tunnels and Madrid Río. It is remarkable, for example, that the cases of people being hospitalized with health issues related to the inhalation of $\mathrm{NO}_{\mathrm{x}}$ have decreased since the renovation of the road, even when $\mathrm{NO}_{\mathrm{x}}$ still exceeds the maximum limits established by Spanish law [10]. The burial of the road and creation of the Madrid Río park also redefined the land use of the area, enhancing leisure and cultural activities available to residents and visitors. They also influenced the mobility patterns in the area, increasing the permeability among the neighborhoods that had been historically separated due to the barrier of the Manzanares river and the M-30 [84]. The purpose of the renovation design was to improve the accessibility of the section, not only for drivers but also for pedestrians, creating a park with slopes ranging from $4 \%$ to $6 \%$, a wide network of pedestrian paths, $30 \mathrm{~km}$ of segregated bike lanes, and bridges that cross the river $[14,61]$. The park also enhances the leisure, sport and cultural activities with development of children's playgrounds, basketball, handball and tennis courts, and cultural centers [13]. Thus, this significant improvement in the conditions of the collective use of the space has been positively perceived by the population, increasing social comfort in the area. Again, it should be highlighted that these indicators are directly dependent on the design of the work and the application of new materials has null or low impact on these indicators.

In view of the result obtained from the MIVES analysis, although it may be concluded that the alternative existing nowadays shows a high level of sustainability, it could have been improved by using high-performance materials. It should also be considered that the use of these kinds of materials would have involved longer construction times, higher construction costs, and arguably recruitment of a more specialized labor force.

The use of conventional materials would lead to the need of a more exhaustive maintenance (one which should be carried out as soon as needed) to avoid possible structural damage derived from durable issues. It is then vital to count on a thorough and detailed inspection program, involving regular and specific inspections, and perform maintenance actuations where needed [68,85].

Such maintenance may also improve, to some extent, the state of the infrastructure if it seeks not only to repair the damage but also prevent it from appearing again [68], applying durable procedures 
such as anti-carbonation painting and hydrofugant coatings in presence of water, improving the drainage systems or the waterproofing of structural joints.

\section{Conclusions}

MIVES is thus a powerful tool and a highly suitable method available to evaluate the sustainability of the structures in various scenarios in which a high number of heterogeneous factors are involved. This is due to its capability to combine socio-economic and environmental and criteria, as well as qualitative and quantitative indicators.

The results of the application of such a method to assess the sustainability of the works performed on the M-30, consideration of the alternatives (a non-buried M-30, buried M-30 by using conventional materials and buried M-30 with improved materials) could be summarized as follows: the burial of the south-west section of the M-30 has significantly improved the sustainability of the road and surrounding areas. Thus, the above mentioned environmental and socio-economic benefits provided by the renovation of the layout outweigh the disturbance and interruption generated during the works.

The level of sustainability obtained could have been slightly improved if high-performance materials had been used, although the use of new materials would have involved longer construction times, higher construction costs and arguably recruitment of a more specialized labor force. It should also be considered that the use of improved materials would have only concerned indicators that evaluated economic and environmental criteria. This would be because several environmental and, especially, socio-economic indicators are primarily dependent on the design of the infrastructure and not only on the materials used during construction.

Author Contributions: Conceptualization, M.G.A. and J.C.G.; methodology, M.G.A. and J.C.G.; validation, M.G.A., J.C.G. and T.R.; formal analysis, M.G.A., J.C.G., L.L.-d.A. and A.P.P.-F.; investigation, L.L.-d.A. and A.P.P.-F.; resources, L.L.-d.A. and A.P.P.-F.; data curation, L.L.-d.A. and A.P.P.-F.; writing-original draft preparation, L.L.-d.A. and A.P.P.-F.; writing-review and editing, M.G.A., J.C.G., L.L.-d.A. and A.P.P.-F.; visualization, L.L.-d.A. and A.P.P.-F.; supervision, M.G.A., T.R. and J.C.G.; project administration, M.G.A., T.R. and J.C.G. All authors have read and agreed to the published version of the manuscript.

Funding: This research was funded by Ministry of Economy, Industry and Competitiveness of Spain by grant PID2019-108978RB-C31, and Enterprise University Chair Calle30-UPM.

Acknowledgments: The authors gratefully acknowledge the financial support provided by the Ministry of Economy, Industry and Competitiveness of Spain by means of the Research Fund Project PID2019-108978RB-C31. They also offer their gratitude to Calle 30 for supporting the Enterprise University Chair Calle30-UPM.

Conflicts of Interest: The authors declare no conflict of interest.

\section{References}

1. Perez-Prada, F.; Monzon, A. How lowering speed limits in an urban highway affects traffic perfirmance and emissions: The caso of Madrid M-30 ring-road. In Proceedings of the XI Congreso de Ingeniería del Transporte (CIT 2014), Santander, Spain, 9-11 June 2014; pp. 1-16. Available online: http://oa.upm.es/31150/ (accessed on 19 October 2020).

2. Núñez-Alonso, D.; Pérez-Arribas, L.V.; Manzoor, S.; Caceres, J.O. Statistical Tools for Air Pollution Assessment: Multivariate and Spatial Analysis Studies in the Madrid Region. J. Anal. Methods Chem. 2019, 2019, 1-9. [CrossRef] [PubMed]

3. Hill, T.; Henderson, A.; Lebkuecher, T.; Moorhead, M.; Weekley, G. Madrid: Sustainability and Green Space Initiatives. Urban Sustainability Programs: Case Studies. David J. Hess, Sociology Department, Vanderbilt University, USA. 2012. Available online: http://www.emory.edu/home/life/sustainability.html (accessed on 19 October 2020).

4. Tatari, O.; Kurmapu, D. Sustainability assessment of highways: A Malmquist index of U.S. states. In Proceedings of the 2011 IEEE International Symposium on Sustainable Systems and Technology, Chicago, IL, USA, 16-18 May 2011; pp. 1-6.

5. Aguado de Cea, A.; Gálvez, J.C.; Renter, A.A.; Álvarez, P.P.; Fernández-Ordoñez, D. Evaluación de la sostenibilidad de carreteras. Carreteras 2017, 4, 8-19. 
6. A Janssen, M.; Anderies, J.M.; Baeza, A.; Breetz, H.L.; Jasinski, T.; Shin, H.C.; Vallury, S. Highways as coupled infrastructure systems: An integrated approach to address sustainability challenges. Sustain. Resilient Infrastruct. 2019, 1-12. [CrossRef]

7. Mansourianfar, M.H.; Haghshenas, H. Micro-scale sustainability assessment of infrastructure projects on urban transportation systems: Case study of Azadi district, Isfahan, Iran. Cities 2018, 72, 149-159. [CrossRef]

8. Perez-Prada, F.; Monzon, A. Ex-post environmental and traffic assessment of a speed reduction strategy in Madrid's inner ring-road. J. Transp. Geogr. 2017, 58, 256-268. [CrossRef]

9. De Cáceres, A.M.; Mayora, J.M.P.; Báez, L.V.; Fernández, J.B.; González, A.d.; Flores, M.P. El programa de mejoras de la M-30 en el contexto de una estrategia de movilidad sostenible para Madrid. Rev. Obras Públicas 2005, 3454, 7-26.

10. Consejería de Economía y Hacienda de la Comunidad de Madrid. "Informe Final: Estudio de caso. Impactos del Proyecto de Soterramiento de Calle 30. Exp. 300/2017/00911," Madrid (Spain). 2019. Available online: https://www.madrid.es/UnidadWeb/Contenidos/EspecialInformativo/AuditoriaDeuda/ InformesImpacto/ObraSoterramientoM30.pdf (accessed on 19 October 2020).

11. Paricio, J.I.M. Los túneles de la Calle 30 de Madrid. Características. Saf. Fire Tech./Bezp. Tech. Pozar. 2013, 30, 127-135.

12. Llorente, I.D.; Álvarez, E.A.; Antelo, I.E. Ventilación en caso de incendio y gestión medioambiental en los túneles de Calle 30. In Ingeo Túneles; López Jimeno, C., Ed.; ETSI Industriales, UPM: Madrid, Spain, 2009.

13. Hernández-Lamas, P.; Gavilán, A.R.; Bernabeu-Larena, J. Parks and roads build the cities: The M-30 and Madrid-Río project, building landscape. In Proceedings of the 11th International Conference Virtual City and Territory: Back to the Sense of the City, Krakow, Poland, 6-8 July 2016; pp. 415-428.

14. Reig, I.B.; Roig, L.B.; Marcenac, V.; Luján, N.S. Linear parks understood as vertebration instruments of the city. In Proceedings of the 24th ISUF 2017-City and Territory in the Globalization Age, Valencia, Spain, 27-29 September 2017; pp. 983-993. [CrossRef]

15. Sanjuán, M.Á.; Andrade, C.; Mora, P.; Zaragoza, A. Carbon Dioxide Uptake by Cement-Based Materials: A Spanish Case Study. Appl. Sci. 2020, 10, 339. [CrossRef]

16. Enfedaque, A.; Alberti, M.G.; Gálvez, J.C.; Rivera, M.; Simón-Talero, J.M. Can Polyolefin Fibre Reinforced Concrete Improve the Sustainability of a Flyover Bridge? Sustainability 2018, 10, 4583. [CrossRef]

17. Fernández Cánovas, M. Hormigón, 10th ed.; Colegio de Ingenieros de Caminos, Canales y Puertos: Madrid, Spain, 2013.

18. San José, J.T.; Josa, A. Planteamiento MIVES para la evaluación. El caso de la EHE. Cem. Hormigón 2008, 913, 28-36.

19. Spanish Minister of Public Works. EHE-Spanish Structural Concrete Code; Ministerio de Fomento: Madrid, Spain, 2008.

20. San-José, J.T.; Aprea, I.G. A system approach to the environmental analysis of industrial buildings. Build. Environ. 2010, 45, 673-683. [CrossRef]

21. Losada, R.; Rojí, E.; Cuadrado, J. La Medida de la Sostenibilidad en Edificación Industrial; Losada, R., Rojí, E., Cuadrado, J., Eds.; ETSI Press: Bilbao, Spain, 2006.

22. Pons, O.; De La Fuente, A.; Aguado, A. The Use of MIVES as a Sustainability Assessment MCDM Method for Architecture and Civil Engineering Applications. Sustainability 2016, 8, 460. [CrossRef]

23. Pons, O.; Wadel, G.; Pons, O. Environmental impacts of prefabricated school buildings in Catalonia. Habitat Int . 2011, 35, 553-563. [CrossRef]

24. Alberti, M.G.; Gálvez, J.; Enfedaque, A.; Carmona, A.; Valverde, C.; Pardo, G. Use of Steel and Polyolefin Fibres in the La Canda Tunnels: Applying MIVES for Assessing Sustainability Evaluation. Sustainability 2018, 10, 4765. [CrossRef]

25. Cafiso, S.; Di Graziano, A.; Kerali, H.R.; Odoki, J.B. Multicriteria Analysis Method for Pavement Maintenance Management. Transp. Res. Rec. J. Transp. Res. Board 2002, 1816, 73-84. [CrossRef]

26. Pujadas, P.; Pardo-Bosch, F.; Aguado-Renter, A.; Aguado, A. MIVES multi-criteria approach for the evaluation, prioritization, and selection of public investment projects. A case study in the city of Barcelona. Land Use Policy 2017, 64, 29-37. [CrossRef]

27. Stojčić, M.; Zavadskas, E.K.; Pamučar, D.; Stević, Ž.; Mardani, A. Application of MCDM Methods in Sustainability Engineering: A Literature Review 2008-2018. Symmetry 2019, 11, 350. [CrossRef]

28. Kohler, N.; Moffatt, S. Life-cycle analysis of the built environment. Build. Des. Constr. 2003, 26, 17-21. 
29. Malin, N. Life cycle assessment for whole buildings: Seeking the holy grail. Build. Des. Constr. 2005, 46, 6-11.

30. International Organization for Standardization (ISO). 14040: Environmental Management. Life Cycle Assessment. Principles and Framework; ISO: Geneva, Switzerland, 2006.

31. Ortiz, O.; Castells, F.; Sonnemann, G. Sustainability in the construction industry: A review of recent developments based on LCA. Constr. Build. Mater. 2009, 23, 28-39. [CrossRef]

32. European Comisssion. International Reference Life Cycle Data System (ILCD) Handbook: General Guide for Life Cycle Assessment. Detailed Guidance; Institute for Environmental Sustainability: Ispra, Italy, 2010.

33. Buyle, M.; Braet, J.; Audenaert, A. Life cycle assessment in the construction sector: A review. Renew. Sustain. Energy Rev. 2013, 26, 379-388. [CrossRef]

34. Glass, J.; Dyer, T.; Georgopoulos, C.; Goodier, C.I.; Paine, K.; Parry, T.; Baumann, H.; Gluch, P. Future use of life-cycle assessment in civil engineering. Proc. Inst. Civ. Eng. Constr. Mater. 2013, 166, 204-212. [CrossRef]

35. Asiedu, Y.; Gu, P. Product life cycle cost analysis: State of the art review. Int. J. Prod. Res. 2010, 37-41. [CrossRef]

36. Cabeza, L.F.; Rincón, L.; Vilariño, V.; Pérez, G.; Castell, A. Life cycle assessment (LCA) and life cycle energy analysis (LCEA) of buildings and the building sector: A review. Renew. Sustain. Energy Rev. 2014, 29, $394-416$. [CrossRef]

37. Allesch, A.; Brunner, P.H. Material Flow Analysis as a Decision Support Tool for Waste Management: A Literature Review. J. Ind. Ecol. 2015, 19, 753-764. [CrossRef]

38. Lanfang, L.; Issam, S.; Chong, W.K.; Christopher, H. Integrating G2G, C2C and resource flow analysis into life cycle assessment framework: A case of construction steel's resource loop. Resour. Conserv. Recycl. 2015, 102, 143-152. [CrossRef]

39. Todd, J.A.; Crawley, D.; Geissler, S.; Lindsey, G. Comparative assessment of environmental performance tools and the role of the Green Building Challenge. Build. Res. Inf. 2001, 29, 324-335. [CrossRef]

40. Aguado de Cea, D.; Gálvez, A.; Fernández-Ordoñez, J.C.; de la Fuente, A. Sustainability evaluation of the concrete structures. In Proceedings of the Second International Conference on Concrete Sustainability (ICCS-16), Madrid, Spain, 13-15 June 2016; Gálvez, J.C., Aguado, A., Fernández-Ordóñez, D., Eds.; International Center for Numerical Methods in Engineering (CIMNE): Madrid, Spain, 2016; pp. 58-71.

41. Alarcon, B.; Aguado, A.; Manga, R.; Josa, A. A Value Function for Assessing Sustainability: Application to Industrial Buildings. Sustainability 2010, 3, 35-50. [CrossRef]

42. Saaty, T.L.; Vargas, L.G. How to Make a Decision. Int. Ser. Oper. Res. Manag. Sci. 2012, 175, 1-21. [CrossRef]

43. Pardo-Bosch, F.; Aguado, A. Sustainability as the key to prioritize investments in public infrastructures. Environ. Impact Assess. Rev. 2016, 60, 40-51. [CrossRef]

44. De La Fuente, A.; Armengou, J.; Pons, O.; Aguado, A. Multi-criteria decision-making model for assessing the sustainability index of wind-turbine support systems: Application to a new precast concrete alternative. J. Civ. Eng. Manag. 2016, 23, 194-203. [CrossRef]

45. De La Fuente, A.; Pons, O.; Josa, A.; Aguado, A. Multi-Criteria Decision Making in the sustainability assessment of sewerage pipe systems. J. Clean. Prod. 2016, 112, 4762-4770. [CrossRef]

46. Hosseini, S.M.A.; De La Fuente, A.; Pons, O. Multicriteria Decision-Making Method for Sustainable Site Location of Post-Disaster Temporary Housing in Urban Areas. J. Constr. Eng. Manag. 2016, 142, 04016036. [CrossRef]

47. Hosseini, S.M.A.; De La Fuente, A.; Pons, O. Multi-criteria decision-making method for assessing the sustainability of post-disaster temporary housing units technologies: A case study in Bam, 2003. Sustain. Cities Soc. 2016, 20, 38-51. [CrossRef]

48. Pons, O.; De La Fuente, A. Integrated sustainability assessment method applied to structural concrete columns. Constr. Build. Mater. 2013, 49, 882-893. [CrossRef]

49. Hosseini, S.A.; Pons, O.; De La Fuente, A. A combination of the Knapsack algorithm and MIVES for choosing optimal temporary housing site locations: A case study in Tehran. Int. J. Disaster Risk Reduct. 2018, 27, 265-277. [CrossRef]

50. San José, J.; Cuadrado, J. Industrial building design stage based on a system approach to their environmental sustainability. Constr. Build. Mater. 2010, 24, 438-477. [CrossRef]

51. Reyes, J.P.; San-José, J.T.; Cuadrado, J.; Sancibrian, R. Health \& Safety criteria for determining the sustainable value of construction projects. Saf. Sci. 2014, 62, 221-232. [CrossRef] 
52. Quale, J.; Eckelman, M.J.; Williams, K.W.; Sloditskie, G.; Zimmerman, J.B. Construction Matters: Comparing Environmental Impacts of Building Modular and Conventional Homes in the United States. J. Ind. Ecol. 2012, 16, 243-253. [CrossRef]

53. San-José, J.; Losada, R.; Cuadrado, J.; Garrucho, I. Approach to the quantification of the sustainable value in industrial buildings. Build. Environ. 2007, 42, 3916-3923. [CrossRef]

54. Ormazabal, G.; Viñolas, B.; Aguado, A. Enhancing Value in Crucial Decisions: Line 9 of the Barcelona Subway. J. Manag. Eng. 2008, 24, 265-272. [CrossRef]

55. Pardo-Bosch, F.; Aguado, A. Investment priorities for the management of hydraulic structures. Struct. Infrastruct. Eng. 2014, 11, 1-14. [CrossRef]

56. Aguado, A.; Del Caño, A.; De La Cruz, M.P.; Gómez, D.; Josa, A. Sustainability Assessment of Concrete Structures within the Spanish Structural Concrete Code. J. Constr. Eng. Manag. 2012, 138, 268-276. [CrossRef]

57. Del Caño, A.; Gómez, D.; De La Cruz, M.P. Uncertainty analysis in the sustainable design of concrete structures: A probabilistic method. Constr. Build. Mater. 2012, 37, 865-873. [CrossRef]

58. Viñolas Prat, B.; Cortés, F.; Marques, A.; Garcia-Tornel, A.J.; de Cea, A.A. Mives: Modelo Integrado De Valor Para Evaluaciones De Sostenibilidad. In II Congrés Internacional de Mesura I Modelització de La Sostenibilitat; International Center for Numerical Methods in Engineering (CIMNE): Barcelona, Spain, 2009; pp. 1-24.

59. Junyent, R. Evaluating the Social Impact of Urban Highways. Application to the Outer Ring Road in Barcelona; Directorate-General for Research, European Commission: Luxembourg, 2001.

60. Ristić, M.; Milojević, R.; Radosavljević, M. Long-term provisions as a security mechanism due to lack of quality. Èkon. Horiz. 2019, 21, 75-89. [CrossRef]

61. Abdul-Rahman, H.; Thompson, P.; Whyte, I. Capturing the cost of non-conformance on construction sites. Int. J. Qual. Reliab. Manag. 1996, 13, 48-60. [CrossRef]

62. Colvile, R.; Hutchinson, E.; Mindell, J.S.; Warren, R. The transport sector as a source of air pollution. Atmos. Environ. 2001, 35, 1537-1565. [CrossRef]

63. Van Essen, H.; Schroten, A.; Otten, M.; Sutter, D.; Schreyer, C.; Zandonella, R.; Maibach, M.; Doll, C.; Friedrich, R. External Costs of Transport in Europe; Edward Elgar Publishing: Delft, The Netherlands, 2013.

64. Sánchez, M.; López-Mosquera, N.; Lera-Lopez, F.; Faulin, J. An Extended Planned Behavior Model to Explain the Willingness to Pay to Reduce Noise Pollution in Road Transportation. J. Clean. Prod. 2018, 177, 144-154. [CrossRef]

65. Perini, K. Madrid Río, Spain-Strategies and Techniques. In Urban Sustainability and River Restoration; Wiley: Hoboken, NJ, USA, 2016; pp. 117-126.

66. Stevenson, M. Social impact assessment of major roads. In Proceedings of the 20th World Road Congress, Montreal, QC, Canada, 3-9 September 1995.

67. Cramphorn, B.; Davies, R. The social impact of roads. Aust. Plan. 2004, 41, 46-47. [CrossRef]

68. González, J.; Ley Urzaiz, J.; Menéndez Corral, A.B.; Moraleda Palmero, J.; Navareño Rojo, A.; Poy López, I.; Pulido Sánchez, I.; Simón-Talero Muñoz, J.; Tocino de la Iglesia, A.; Velando Cabañas, C. Guía para la Redacción del plan de Mantenimiento de Puentes; ACHE: Madrid, Spain, 2015.

69. De Fomento, M. Orden Circular 35/2014 Sobre Criterios De Aplicación De Sistemas De Contención De Vehículos; Ministerio de Fomento: Madrid, Spain, 2014.

70. De Presidencia, M. Real Decreto 1367/2007, de 19 de Octubre, por el que se Desarrolla la Ley 37/2003, de 17 de Noviembre, del Ruido, en lo Referente a Zonificación Acústica, Objetivos de Calidad y Emisiones Acústicas. BOE-A-2007-18397. 2007. Available online: https://www.boe.es/buscar/act.php?id=BOE-A-2007-18397 (accessed on 19 October 2020).

71. Ortiz de Andrés, I. Efecto de ondas concentricas en la ciudad. El impacto de los tuneles de la M-30 medido en el mercado inmobiliario limftrofe. Rev. Obras Publicas 2016, 163, 63-68.

72. López Cade, P. Turismo Urbano Accesible en los Parque y Jardines Urbanos Públicos del Buen Retiro y de Madrid Rio; Universidad de Jaén: Jaén, Spain, 2014.

73. Corres Peiretti, H.; Veiguela, C.S.; Espinel, J.D.G.; Herrera, H.I.C.; Moreno, J.G.; Ligero, V.C.; Carreras, R.L.; Albione, A.V. Aplicación de tecnologías avanzadas del hormigón en las pasarelas en cascara sobre el río Manzanares para el proyecto Madrid Río. Rev. Obras Publicas 2010, 157, 7-18.

74. Zhou, F.; Lydon, F.; Barr, B. Effect of coarse aggregate on elastic modulus and compressive strength of high performance concrete. Cem. Concr. Res. 1995, 25, 177-186. [CrossRef] 
75. Kılıç, A.; Atiş, C.; Teymen, A.; Karahan, O.; Özcan, F.; Bilim, C.; Özdemir, M. The influence of aggregate type on the strength and abrasion resistance of high strength concrete. Cem. Concr. Compos. 2008, 30, 290-296. [CrossRef]

76. Sideris, K.; Anagnostopoulos, N.S. Durability of normal strength self-compacting concretes and their impact on service life of reinforced concrete structures. Constr. Build. Mater. 2013, 41, 491-497. [CrossRef]

77. Müller, H.S.; Haist, M.; Vogel, M. Assessment of the sustainability potential of concrete and concrete structures considering their environmental impact, performance and lifetime. Constr. Build. Mater. 2014, 67, 321-337. [CrossRef]

78. De Presidencia, M. Real Decreto 102/2011, de 28 de Enero, Relativo a la Mejora de la Calidad del Aire. BOE-A-2011-1645. 2011. Available online: https://www.boe.es/eli/es/rd/2011/01/28/102/con (accessed on 19 October 2020).

79. Turner, B. The Statesman's Yearbook; Organisation for Economic Co-Operation and Development (OECD): Paris, France, 2005; pp. 86-88.

80. Systematic, C. Moving Cooler: An Analysis of Transportation Strategies for Reducing Greenhouse Gas Emissions; Urban Land Institute: Washington, DC, USA, 2009.

81. Meyer, M.; Burbank, C.; Zeimer, L.; Porter, C.; Potter, J.; Wilson, J. Incorporating Greenhouse Gas Emissions into the Collaborative Decision-Making Process; SHRP 2 Report S2-C09-RR-1; National Academies of Sciences, Engineering and Medicine: Washington, DC, USA, 2013.

82. Yoshioka, K.; Obata, D.; Nanjo, H.; Yokozeki, K.; Torichigai, T.; Morioka, M.; Higuchi, T. New Ecological Concrete that Reduces $\mathrm{CO}_{2}$ Emissions Below Zero Level $\sim$ New Method for $\mathrm{CO}_{2}$ Capture and Storage . Energy Procedia 2013, 37, 6018-6025. [CrossRef]

83. Cansinos Bajo, A. Guía de Iluminación en Túneles e Infraestructuras Subterráneas; FENERCOM: Madrid, Spain, 2015. Available online: https://www.fenercom.com/wp-content/uploads/2015/06/Guia-de-Iluminacion-enTuneles-e-Infraestructuras-Subterraneas-fenercom-2015.pdf (accessed on 19 October 2020).

84. Faustino, A.D.S. El río Manzanares en su paso por los tejidos urbanos de Madrid: El juego de posibilidades entre una biofilia hídrica cotidiana y la recuperación ecológica riparia = The Manzanares River as it passes through the urban fabric of Madrid: The balance of possibilities between a daily water biophilia and the ecological riparian recovery. Territ. Form. 2018, 20-39. [CrossRef]

85. DGC. Guía Para la Realizacion de Inspecciones Principales de Obras de Paso en la Red de Carreteras del Estado. 2012. Available online: https://www.mitma.gob.es/recursos_mfom/0870250.pdf (accessed on 19 October 2020).

Publisher's Note: MDPI stays neutral with regard to jurisdictional claims in published maps and institutional affiliations.

(C) 2020 by the authors. Licensee MDPI, Basel, Switzerland. This article is an open access article distributed under the terms and conditions of the Creative Commons Attribution (CC BY) license (http://creativecommons.org/licenses/by/4.0/). 